\title{
FACTORS AFFECTING SOCIALLY RESPONSIBLE INVESTMENT INTENTIONS INVESTORS IN SURABAYA
}

\author{
Jesselyn Geraldine ${ }^{1}$, R. Shanti D. Ottemoesoe ${ }^{2}$ \\ 1,2 Finance and Investment Program, Faculty of Business and Economics, Petra Christian University \\ Jl. Siwalankerto 121-131, Surabaya \\ E-mail: ${ }^{1}$ d11170080@john.petra.ac.id
}

\begin{abstract}
Socially responsible investment (SRI) is an investment that considers financial goals and non-financial goals such as social, ethical, and environmental-related matters. This study aims to examine the factors that influence SRI intentions on 113 investors in Surabaya using the theory of reasoned action (TRA), attitude and subjective norms, and three additional variables, namely moral norms, financial literacy, and returns. The research data was obtained from distributing questionnaires through Google Forms. Data processing is carried out using Partial Least Square's method with the SmartPLS application. The study results found that all study's independent variables had a significant positive effect on SRI intentions.
\end{abstract}

Keywords: Socially Responsible Investment, Theory of Reasoned Action, Moral Norms, Financial Literacy, Return.

\section{INTRODUCTION}

Socially responsible investment (SRI) is an investment that considers financial goals and nonfinancial goals such as social, ethical, and environmental (Camilleri, 2017). The Sustainable and Responsible Investment (SRI)-KEHATI Stock Index. SRI is an investment free from the negative list of core businesses such as weapons, tobacco, and alcohol, meets financial aspects such as minimum market capitalization, and fulfills fundamental elements such as environmental, employment, and human rights (Kehati, 2021). The SRI-KEHATI index, the only reference to Indonesia's principle of sustainable investment, has shown better price growth than the Composite Stock Price Index $(\mathrm{JCl})$ and LQ45 since its issuance. The positive performance of SRI makes research on SRI intentions interesting to do. This is because, through research on SRI intentions, investors' interest in investing in SRI can reflect the potential of SRI in the future. This research will be conducted in Surabaya with a population of stock investors. The reason researched is Surabaya's investment climate which shows growth. In 2020, East Java's investment realization amounted to Rp. 78.30 trillion, which managed to rank first in Indonesia with a growth of $33.80 \%$. Surabaya provided the largest contribution from this achievement, amounting to $21.46 \%$ (East Java DPMPTSP, 2021). The sample criteria for this research are stock investors who have a basic understanding of SRI. Through this study, the factors that can significantly influence the SRI intentions of investors can be seen.

Intentions are defined as the will (desire in the heart) to do something (KBBI Daring, 2016). The theory of reasoned action explains that intentions are influenced by the attitude towards the behavior and subjective norms (Saputra, et al., 2021). Attitude describes an attitude in a positive or negative response to a behavior. Meanwhile, subjective norms represent other individuals or groups' social influence that encourages a person to follow what is considered correct by his social environment (Venkatesh \& Davis, 2000). According to Adam \& Shauki (2014), attitude explains SRI intentions because the attitude towards SRI stimulates investors' intentions to choose SRI. For subjective norms, Adam \& Shauki (2014) explain that in a social environment dominated by good perceptions of SRI, social influences arise that encourage investors to choose SRI.

Other factors are considered necessary in research on intentions (Conner \& Armitage, 1998; Hagger et al., 2002). For individuals who are not easily influenced by subjective norms (Hasan \& Suciarto, 2020), moral norms, which are values that everyone closely holds regarding whether or not a behavior is morally correct, can explain the variety of factors that influence SRI intentions. In his research on SRI intentions, Raut et al. (2020) found a significant influence of moral norms on SRI intentions in India. In this modern era, the financial world continues to develop, resulting in the 
emergence of new financial products that are increasingly complex (Garg \& Singh, 2018). Incorporating non-financial preferences in a financial decision makes SRI a complex instrument (Borgers \& Pownall, 2014). In addition, Swanson et al. (2006) explained that adequate knowledge creates acceptability that can motivate someone to do so. Thus, investors' financial literacy is considered a factor that can influence SRI intentions (Raut et al., 2020).

Lewis \& Mackenzie (2000) explained that good SRI performance could attract investors who are not concerned with environmental concerns and only aim to obtain returns. Research conducted by Raut et al. (2020) found the effect of return significant on SRI intentions. This finding explains that if the investment instruments of responsible issuers have good returns, the intention to choose SRI will increase. This study incorporates additional variables beyond attitude and subjective norms to the reasoned action theory in looking at investors' SRI intentions. Ajzen (1991) states that the theory of reasoned action is a theory that is still open for further elaboration. If a coherent research model with certain conditions is to be obtained, additional related variables are needed to support the basic theory (Conner \& Armitage, 1998). Therefore, moral norms, financial literacy, and return are used as additional variables in this study.

\section{LITERATURE REVIEW}

\section{Behavioral Intentions}

Behavioral intentions are defined as the consumer's desire to behave in a certain way to own, dispose of, and use a product or service (Mowen, 2002). Zeitham et al. (1996) said research on behavioral intentions to consumers is the best measurement to predict future purchase behavior. In its development, the concept of behavioral intentions is expressed as an indicator of the extent. A person is willing to try and how much effort is planned to be expended (Ajzen, 1991). The theory of reasoned action states that behavioral intentions are influenced by the attitude towards behavior and subjective norms (Saputra, et al., 2021). This theory predicts behavioral intentions in various circumstances and is designed to explain most human behavior (Pavlou \& Fygenson, 2006). The inclusion of additional variables in the theory of reasoned action can increase the ability of the model to explain intentions (Hagger et al., 2002). In researching SRI intentions, moral norms, financial literacy, and returns are additional variables that are also included.

\section{Relationship Between Concepts}

In its development, other factors are considered necessary to be included in research on intentions (Conner \& Armitage, 1998; Hagger et al., 2002). Research on SRI intentions in this study incorporates attitude and subjective norms into the theory of reasoned action, with moral norms, financial literacy, and returns. Attitude is defined as a person's attitude in the form of a positive or negative response to an object that affects his behavior towards that object (Hogg \& Smith, 2007; Wahono \& Pertiwi, 2020). Attitude arises from the impact that will be caused by behavior, which will then affect the intention to behave towards that behavior (Fishbein \& Ajzen, 1975). Implemented in $\mathrm{SRI}$, investors who want to achieve non-financial goals such as environmental awareness will have a positive attitude towards responsible issuers, increasing investors' SRI intentions. The results of previous studies found a significant effect of attitude on SRI intentions (Adam \& Shauki, 2014; Raut et al., 2020). Attitude towards SRI intentions is seen through statements that measure positive or negative responses given by respondents to socially responsible investments (Taylor \& Todd, 1995; Chen, 2007; Hayhoe et al., 1999).

Subjective norms are perceptions of other individuals that can influence a person's behavior (Ham et al., 2015). Perceptions of other individuals or community groups that are considered important give rise to an impetus for someone to behave in accordance with what is considered correct by the other individual or group. If other individuals think that investing in socially responsible investment (SRI) is a good action, then that individual will advise investors to choose SRI in their investments. If the perception of SRI owned by other individuals is considered essential by investors, this can affect the SRI intentions of investors. Research that has been conducted has found subjective norms 
as a significant factor influencing SRI intentions (Adam \& Shauki, 2014; Raut et al., 2020). This explains that the thoughts of other individuals considered necessary by investors about SRI form the social influences that motivate them to invest in SRI. Subjective norms towards SRI intentions are seen from a statement that measures the adoption of socially responsible investment by the respondent's social environment and the environmental incentives to invest in socially responsible investment (Taylor \& Todd, 1995; Hayhoe et al., 1999; Subandi \& Basana, 2021).

Moral norms are a person's perception of the right or wrong of behavior that will affect whether or not the behavior is implemented (Ajzen, 1991; Gabriel \& Linawati, 2020). Through their research, Kaiser \& Scheuthle (2003) said that moral norms become the most important factor in predicting a person's intentions when personal desires meet social problems. Previous research conducted by Liu et al. (2019) found a significant influence of moral norms on green product purchase intentions. In their research, Jung et al. (2016) stated that someone supported by high moral norms is more concerned about the environment, leading to a tendency to implement behavior pro-environmental. Liu et al. (2019) concluded that moral norms influence pro-environmental intentions. Moral norms for SRI intentions are seen from statements that measure investors' encouragement to contribute to the environment and socially responsible investment, as well as the personal satisfaction that arises through these contributions (Khare, 2015; Liu et al., 2019; Basana and Tarigan, 2021).

Financial literacy broadly includes a variety of financial knowledge, both basic knowledge of personal finance, savings and loans, insurance, and investment (Chen \& Volpe, 1998; Wahono \& Pertiwi, 2020). Borgers \& Pownall (2014) stated that considering non-financial preferences and goals into financial decisions is very complex for someone with a level of financial literacy. Therefore, good financial literacy enables investors to mix choices for non-financial goals in their financial decisions, encouraging investors' intention to invest in SRI, whose objectives combine the fulfillment of investors' financial and non-financial goals. Financial literacy on SRI intentions is seen from the measurement of financial literacy owned by respondents through questions about interest rates and investment (Stella et al., 2020).

The main objective of investment activities is to obtain returns (Subandi \& Basana, 2021; Gabriel \& Linawati, 2020). Therefore, the return from the SRI investment instrument influences investors in making decisions to invest in SRI. Research by Rosen et al. (1991) found that investors in SRI are not willing to sacrifice returns for social and environmental matters. Therefore, not non-financial aspects but returns from issuers motivate SRI intentions investors. The significant effect of return on SRI intentions proposed by Raut et al. (2020) research indicates that investors intend to invest in $\mathrm{SRI}$ due to the encouragement of returns good issuer. Return on SRI intentions is seen from the measurement of investor confidence and satisfaction with the level of return of instruments socially responsible (Luong \& Ha, 2011).

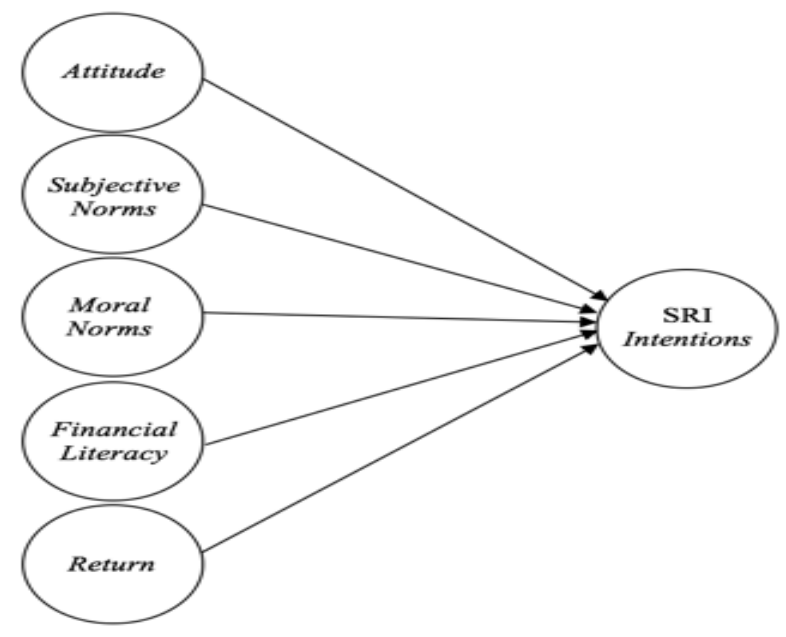

Figure 1. Research Framework 


\section{METHODOLOGY}

The population in this study is stock investors in Surabaya. The reason for choosing stock investors as the research population is the SRI-KEHATI Index, the only socially responsible investment in Indonesia, a stock index. In contrast, the Surabaya research is the investment climate which shows growth. In this study, the sampling technique used was purposive sampling with the criteria of stock investors' basic understanding of SRI. The formula used in determining the number of samples is the formula Lemeshow. Based on the calculation above, the minimum sample size is 70 respondents. The research data were obtained from questionnaires in Google Forms distributed through social media that serve message exchanges such as WhatsApp and Line.

This study uses data analysis techniques Partial Least Square (PLS). The researcher chose this method because PLS could handle many independent variables even though there was multicollinearity. In addition, PLS is suitable for research that explores the expansion of pre-existing theories (Hair, Risher, Sarstedt, \& Ringle, 2019). In this study, the development of the basic theory of reasoned action. In using PLS, must take the following steps to be taken:

1. Compile a diagram path

2. Evaluation of goodness of fit outer model

3. Evaluation of goodness of fit inner model

\section{ANALYSIS AND DISCUSSION}

A diagram path explains the phenomenon being studied or the problem under study. In this study, the model used is a reflective indicator model. Therefore, the relationship between variables will be depicted with a single arrow. Conducted evaluation of the goodness of fit outer model to examine the relationship between variables and indicators that make up the validity and reliability tests. First, the test was conducted to convergent validity measure validity through the value of loading factor, Cronbach's alpha, and average variance extracted (AVE).

Table 1. Results of Loading Factor

\begin{tabular}{ccccccc}
\hline Indicators & Attitude & Fin. Literacy & Return & $\begin{array}{c}\text { Moral } \\
\text { Norms }\end{array}$ & $\begin{array}{c}\text { Subjective } \\
\text { Norms }\end{array}$ & $\begin{array}{c}\text { SRI } \\
\text { Intentions }\end{array}$ \\
\hline 1 & 0.925 & 1,000 & 0.945 & 0.827 & 0.902 & 0.966 \\
2 & 0.718 & & 0.923 & 0.772 & 0.821 & 0.934 \\
3 & 0.846 & & & 0.833 & 0.892 & 0.962 \\
4 & 0.947 & & & 0.809 & 0.795 & \\
5 & 0.792 & & & 0.874 & 0.788 & \\
6 & & & & 0.793 & 0.834 & \\
\hline
\end{tabular}

Based on the results of the loading factor listed in Table 1, all indicators have met the requirements of greater than 0.05 .

Table 2. Results Cronbach's Alpha and Average Variance Extracted (AVE)

\begin{tabular}{lcc}
\hline \multicolumn{1}{c}{ Variable } & Cronbach's Alpha & AVE \\
\hline Attitude & 0.901 & 0.722 \\
Financial Literacy & 1,000 & 1,000 \\
Return & 0.855 & 0.873 \\
Moral Norms & 0.902 & 0.670 \\
SRI Intentions & 0.951 & 0.910 \\
Subjective Norms & 0.916 & 0.705 \\
\hline
\end{tabular}

Based on the results of Cronbach's alpha shown in Table 2, all indicators have met the requirements of Cronbach's alpha greater than 0.70. Furthermore, in Table 2, all indicators have met the requirements for an AVE greater than 0.50. Therefore, all indicators have met the convergent test validity and can be continued to the next test. Then, the test was carried out discriminant validity which measured the validity through the value cross-loading and the Fornell-Larcker criterion. 
Table 3. The Results of Cross Loading

\begin{tabular}{ccccccc}
\hline & Attitude & Fin. Literacy & Return & $\begin{array}{c}\text { Moral } \\
\text { Norms }\end{array}$ & $\begin{array}{c}\text { Subjective } \\
\text { Norms }\end{array}$ & $\begin{array}{c}\text { SRI } \\
\text { Intentions }\end{array}$ \\
\hline AT1 & $\mathbf{0 , 9 2 5}$ & 0,788 & 0,734 & 0,816 & 0,708 & 0,905 \\
AT2 & $\mathbf{0 , 7 1 8}$ & 0,482 & 0,358 & 0,556 & 0,313 & 0,526 \\
AT3 & $\mathbf{0 , 8 4 6}$ & 0,589 & 0,512 & 0,615 & 0,433 & 0,668 \\
AT4 & $\mathbf{0 , 9 4 7}$ & 0,788 & 0,680 & 0,780 & 0,721 & 0,857 \\
AT5 & $\mathbf{0 , 7 9 2}$ & 0,628 & 0,548 & 0,595 & 0,543 & 0,671 \\
FL & 0,787 & $\mathbf{1 , 0 0 0}$ & 0,711 & 0,783 & 0,638 & 0,814 \\
R1 & 0,680 & 0,718 & $\mathbf{0 , 9 4 5}$ & 0,701 & 0,607 & 0,802 \\
R2 & 0,599 & 0,602 & $\mathbf{0 , 9 2 3}$ & 0,621 & 0,536 & 0,681 \\
MN1 & 0,678 & 0,624 & 0,534 & $\mathbf{0 , 8 2 7}$ & 0,479 & 0,651 \\
MN2 & 0,601 & 0,504 & 0,476 & $\mathbf{0 , 7 7 2}$ & 0,389 & 0,560 \\
MN3 & 0,702 & 0,648 & 0,563 & $\mathbf{0 , 8 3 3}$ & 0,603 & 0,647 \\
MN4 & 0,583 & 0,585 & 0,562 & $\mathbf{0 , 8 0 9}$ & 0,508 & 0,591 \\
MN5 & 0,677 & 0,750 & 0,685 & $\mathbf{0 , 8 7 4}$ & 0,589 & 0,792 \\
MN6 & 0,695 & 0,693 & 0,632 & $\mathbf{0 , 7 9 3}$ & 0,602 & 0,722 \\
SN1 & 0,657 & 0,621 & 0,548 & 0,652 & $\mathbf{0 , 9 0 2}$ & 0,674 \\
SN2 & 0,612 & 0,543 & 0,530 & 0,551 & $\mathbf{0 , 8 2 1}$ & 0,622 \\
SN3 & 0,574 & 0,537 & 0,636 & 0,578 & $\mathbf{0 , 8 9 2}$ & 0,710 \\
SN4 & 0,511 & 0,507 & 0,378 & 0,515 & $\mathbf{0 , 7 9 5}$ & 0,516 \\
SN5 & 0,545 & 0,554 & 0,493 & 0,560 & $\mathbf{0 , 7 8 8}$ & 0,587 \\
SN6 & 0,430 & 0,441 & 0,469 & 0,407 & $\mathbf{0 , 8 3 4}$ & 0,546 \\
SRI1 & 0,875 & 0,797 & 0,780 & 0,762 & 0,736 & $\mathbf{0 , 9 6 6}$ \\
SRI2 & 0,769 & 0,749 & 0,732 & 0,749 & 0,640 & $\mathbf{0 , 9 3 4}$ \\
SRI3 & 0,851 & 0,782 & 0,771 & 0,824 & 0,715 & $\mathbf{0 , 9 6 3}$ \\
\hline
\end{tabular}

Table 4. The Results Fornell-Larcker Criterion

\begin{tabular}{lcccccc}
\hline & Attitude & Fin. Literacy & Return & Moral Norms & $\begin{array}{c}\text { SRI } \\
\text { Intentions }\end{array}$ & $\begin{array}{c}\text { Subjective } \\
\text { Norms }\end{array}$ \\
\hline Attitude & $\mathbf{0 . 8 4 9}$ & & & & & \\
Fin. Literacy & 0.787 & $\mathbf{1 . 0 0 0}$ & & & & \\
Return & 0.687 & 0.711 & $\mathbf{0 . 9 3 4}$ & & & \\
Moral Norms & 0.804 & 0.783 & 0.710 & $\mathbf{0 . 8 1 9}$ & & \\
SRI Intentions & $\mathbf{0 . 8 7 3}$ & 0.814 & 0.798 & 0.816 & $\mathbf{0 . 9 5 4}$ & $\mathbf{0 . 8 4 0}$ \\
Subjective Norms & 0.665 & 0.638 & 0.614 & 0.652 & 0.732 & \\
\hline
\end{tabular}

Based on Table 3, the result of cross-loading indicators has had a higher value in the variable than another variable. However, based on the results of the Fornell-Larcker criterion in Table 4, the value of the square root AVE of the variable attitude does not meet the requirements of the Fornell-Larcker criterion because its value is smaller than the correlation of attitude and SRI intentions. The overcome this problem, it is necessary to eliminate the indicator variable AT2, an indicator of the variable attitude with the minor loading factor.

Table 5. Results of Fornell-Larcker Criterion

\begin{tabular}{lcccccc}
\hline & Attitude & Fin. Literacy & Return & Moral Norms & $\begin{array}{c}\text { SRI } \\
\text { Intentions }\end{array}$ & $\begin{array}{c}\text { Subjective } \\
\text { Norms }\end{array}$ \\
\hline Attitude & $\mathbf{0 . 8 8 7}$ & & & & & \\
Fin. Literacy & 0.796 & $\mathbf{1 . 0 0 0}$ & & & & \\
Return & 0.707 & 0.711 & $\mathbf{0 . 9 3 4}$ & & & \\
Moral Norms & 0.801 & 0.783 & 0.710 & $\mathbf{0 . 8 1 9}$ & & \\
SRI Intentions & 0.885 & 0.814 & 0.798 & 0.816 & $\mathbf{0 . 9 5 4}$ & \\
Subjective Norms & 0.691 & 0.638 & 0.614 & 0.652 & 0.732 & $\mathbf{0 . 8 4 0}$ \\
\hline
\end{tabular}

Based on calculations Fornell-Larcker criterion second in Table 5, the whole square root variable AVE meets the requirements. Therefore, based on the results above, the research indicators are valid because they have met the test discriminant validity. 
Table 6. The Results of Reliability Composite

\begin{tabular}{lc}
\hline \multicolumn{1}{c}{ Variable } & Composite Reliability \\
\hline Attitude & 0.936 \\
Financial Literacy & 1.000 \\
Return & 0.932 \\
Moral Norms & 0.924 \\
SRI Intentions & 0.968 \\
Subjective Norms & 0.935 \\
\hline
\end{tabular}

Based on the results shown in Table 6, the entire composite reliability eligible greater than 0.60 . Therefore, each variable indicator has good reliability. Evaluation of the inner model of measurement is carried out between latent variables through the value of $R^{2}$.

Table 7. Results of $R^{2}$ and Adjusted $R^{2}$

\begin{tabular}{ccc}
\hline & R Square & R Square Adjusted \\
\hline SRI Intentions & 0.866 & 0.860 \\
\hline
\end{tabular}

Based on Table 7, adjusted $\mathrm{R}^{2}$ of 0.860 indicates that the variables attitude, subjective norms, moral norms, financial literacy, and returns to explain SRI intentions are $86 \%$, which is at an intense level, and other variables explain the rest. The result of hypothesis testing on table 8.

Table 8. The Results of t-statistics

\begin{tabular}{lccc}
\hline \multicolumn{1}{c}{ The Hypothesis } & Original Sample & t-statistics & Note \\
\hline Attitude -> SRI Intentions & 0.433 & 6.053 & Significant \& positive \\
Fin. Literacy - SRI Intentions & 0.123 & 2,101 & Significant \& positive \\
Return - > SRI Intentions & 0.243 & 3,797 & Significant \& positive \\
Moral Norms -> SRI Intentions & 0.116 & 1,945 & Significant \& positive \\
Subjective Norms $->$ SRI Intentions & 0.130 & 2.905 & Significant \& positive \\
\hline
\end{tabular}

Based on Table 8, all independent research variables, attitude, subjective norms, moral norms, financial literacy, and return, significantly affect SRI intentions. These results are obtained from the calculation of the t-statistics value of each variable above 1,645 , and the value is original sample positive.

Attitude has a significant positive effect on SRI intentions on stock investors in Surabaya. Attitude, A positive towards SRI will encourage investors' intentions to invest in instruments. Socially responsible $\mathrm{SRI}$ is an investment in issuers free from the core business that has a negative impact and pays attention to factors related to the environment and human rights. Therefore, when the investor is a socially conscious person, the concept of investing in SRI will be attractive to Sociallytors. This is because the SRI concept creates a means of obtaining profits in the form of returns investment with special attention to social matters. Therefore, when investors think that investing in SRI is attractive, an attitude positive towards SRI will be formed, increasing their intention to invest in SRI. The results of this study are also in accordance with research conducted by Adam \& Shauki (2014) in Malaysia and Raut et al. (2020) in India. Adam \& Shauki (2014) stated that the results of their research support that when investors have attituded a positive towards SRI, it will stimulate investors' intention to follow norms have a significant positive effect on SRI intentions on stock investors in Surabaya. The findings in this study indicate that subjective criteria lead to social influence that motivates investors' intentions to invest in SRI. This is due to a person's tendency to seek approval and praise from his social environment. Related to SRI, when people are considered necessary by investors such as role models, friends, or parents of investors invest in SRI, the desire to get approval from these individuals makes investors motivated to invest in SRI. Raut et al. (2020) said that investors are encouraged to invest in SRI due to references from their environment which support SRI or feel that investing in SRI is a good choice. Adam \& Shauki's (2014) research explains that this influence is due to the thoughts about SRI owned by individuals considered important by investors to form social results that motivate them to invest in SRI. 
Moral norms have a significant positive effect on SRI intentions on stock investors in Surabaya. This study explains that the moral standards of investors who see that things related to SRI are the right things motivate investors' intentions to invest in SRI. Investors who feel there is a need for them to contribute to saving the environment will avoid harmful or damaging behavior. Therefore, investing in SRI is seen as a form of responsibility or contribution made by investors to support environmental safety in carrying out their investments. Liu et al. (2019) found that moral norms significantly influence green product purchase intentions. Jung et al. (2016) stated that someone with high moral norms tends to apply behavior pro-environmental. Investment in SRI is an environmentally friendly investment so that the findings of Jung et al. (2016) and Liu et al. (2019) support the results of this study.

Financial literacy has a significant positive effect on SRI intentions on stock investors in Surabaya. This study explains that good financial literacy increases investors' intention to invest in SRI. SRI is an investment that considers financial objectives in the form of obtaining returns and non-financial aspects such as social, ethical, and environmental matters. Therefore, the study results, which found that financial literacy had a significant positive effect on SRI intentions, could be explained by the need for financial literacy for high to consider non-financial preferences in a financial decision. Return significantly positive on SRI intentions on stock investors in Surabaya. If investors feel that the return from SRI is good, their intention to invest in SRI will also increase. Rosen et al. (1991) said that investors in SRI are unwilling to sacrifice financial returns for social and environmental-related matters, so return that a good from SRI is an essential factor influencing investors' intention to invest in SRI. Regarding price growth, the SRI-KEHATI Index showed a better performance than the Composite Stock Price Index $(\mathrm{JCl})$ and LQ45. When investors believe that the return that SRI can provide is equal to or even higher than the average market return, SRI will become an attractive investment choice for investors. Based on this finding, a good return from SRI can explain the intention to invest in SRI for investors who only pursue returns without ignoring the non-financial principles in SRI.

\section{CONCLUSIONS AND RECOMMENDATIONS}

Based on the results of the analysis and discussion that has been carried out, we can conclude that the SRI intentions of stock investors in Surabaya are positively influenced by attitude, subjective norms, moral norms, financial literacy, and returns. In terms of attitude, the more positive the attitude of investors towards SRI, the intention to invest in SRI will increase. Furthermore, the higher the social influence, the higher the investor's intention to invest in SRI for subjective norms. Furthermore, the higher the moral norms related to environmental awareness and SRI, the investor's intention to invest in SRI will increase. Moreover, this study explains that good financial literacy increases investors' intention to invest in SRI. Furthermore, the higher the return from SRI instruments, the investor's intention to invest in SRI will increase.

The limitation of this research is that the respondents in this study are dominated by the age group of 21-30, so it is advisable to collect respondents with a more even age group so that the study results can describe all age groups equally. Furthermore, this study uses stock investors in Surabaya as the research object. Therefore, it is expected to expand the thing of analysis to represent a larger population for further research. Furthermore, the measurement of financial literacy in this study uses general measurements. Therefore, for further research, it is recommended to measure the knowledge of specific respondents about SRI so that they can provide more accurate research results.

\section{REFERENCES}

Adam, A.A., \& Shauki, E.R. (2014). Socially Responsible Investment in Malaysia: Behavioral Framework in Evaluating Investors' Decision-Making Process. Journal of Cleaner Production, 224-240.

Ajzen, I. (1991). The Theory of Planned Behavior. Organizational Behavior and Human Decision Processes, $50(2), 179-211$.

Basana, S.R., \& Tarigan, Z.J.H. (2021). The Effect of Essential Information and Disposition Effect on Shifting Decision Investment. Accounting 8(2), 264-276, 10.5267/j.ac.2021.6.015. 
Borgers, A.C., \& Pownall, R.A. (2014). Attitudes towards Socially and Environmentally Responsible Investment. Journal of Behavioral and Experimental Finance, 1, 27-44.

Camilleri, M. (2017). Socially Responsible and Sustainable Investing. In M. Camilleri, Corporate Sustainability, Social Responsibility and Environmental Management (pp. 61-77). Malta: Springer.

Chen, H., \& Volpe, R.P. (1998). An Analysis of Personal Financial Literacy among College Students. Financial Services Review, 7(2), 107-128.

Chen, MF (2007). Consumer Attitudes and Purchase Intentions in Relation to Organic Foods in Taiwan: Moderating Effects of Food-Related Personality Traits. Food Quality and Preferences, 18(7), 1008-1021.

Conner, M., \& Armitage, C.J. (1998). Extending the Theory of Planned Behavior: A Review and Avenues for Further Research. Journal of Applied Social Psychology, 28(15), 1429-1464.

DPMPTSP East Java. (2021, January 27). The Realization of Domestic Investment, East Java is The Highest in Indonesia Throughout 2020.

Gabriel, F., \& Linawati, N. (2020). Pengaruh Financial Capability, Money Attitudes, dan Socioeconomic Status terhadap Adverse Financial Events. International Journal of Financial and Investment Studies, 1(1), 15-20. https://doi.org/10.9744/ijfis.1.1.15-20

Garg, N., \& Singh, S. (2018, January 8). Financial Literacy among Youth. International Journal of Social Economics, 45(1), 173-186.

Hagger, M., Chatzisarantis, N.L., \& Biddle, S.J. (2002, March). A Meta-Analytic Review of the Theories of Reasoned Action and Planned Behavior in Physical Activity: Predictive Validity and the Contribution of Additional Variables. Journal of Sport \& Exercise Psychology, 24(1), 3-32.

Hair, J.F., Risher, J.J., Sarstedt, M., \& Ringle, C.M. (2019). When to Use and How to Report the Results of PLS-SEM. European Business Review.

Ham, M., Jeger, M., \& Ivković, A.F. (2015, January). The Role of Subjective Norms in Forming the Intention to Purchase Green Food. Economic Research-Ekonomska Istraživanja, 28(1), 738-748.

Hasan, H.N., \& Suciarto, S. (2020, January). The Influence of Attitude, Subjective Norm and Perceived Behavioral Control towards Organic Food Purchase Intention. Journal of Management and Business Environment, 1(2), 132-153.

Hayhoe, C., Leach, L., \& Turner, P. (1999). Discriminating the Number of Credit Cards Held by College Students Using Credit and Money Attitudes. Journal of Economic Psychology, 20(643), 656.

Hogg, M.A., \& Smith, J.R. (2007). Attitudes in Social Context: A Social Identity Perspective. European Review of Social Psychology, 18(1), 89-131.

Jung, H.J., Kim, H.J., \& Oh, K.W. (2016). Green Leather for Ethical Consumers in China and Korea: Facilitating Ethical Consumption with Value-Belief-Attitude Logic. Journal of Business Ethics, 135(3), 483-502.

Kaiser, F.G., \& Scheuthle, H. (2003). Two Challenges to A Moral Extension of the Theory of Planned Behavior: Moral Norms and Just World Beliefs in Conservationism. Personality and Individual Differences, 35(5), 1033-1048.

KBBI Online. (2016). Intention. Retrieved May 2020, from KBBI Online: https://kbbi.kemdikbud.go.id/entri/niat

Kehati. (2021). SRI-KEHATI Index. Retrieved June 2021, from Kehati: https://www.kehati.or.id/en/index-srikehati-2/

Khare, A. (2015). Antecedents to Green Buying Behavior: A Study on Consumers in an Emerging Economy. Marketing Intelligence and Planning, 33(3), 309-329.

Lewis, A., \& Mackenzie, C. (2000). Morals, Money, Ethical Investing and Economic Psychology. Human Relations, 53(2), 179-191.

Liu, M.T., Liu, Y., \& Mao, Z. (2019). Moral Norm is the Key: An Extension of the Theory of Planned Behaviour (TPB) on Chinese Consumers' Green Purchase Intention. Asia Pacific Journal of Marketing and Logistics.

Luong, L.P., \& Ha, D.T. (2011). Behavioral Factors Influencing Individual Investors' Decision-Making and Performance.

Mowen, J.C. (2002). Perilaku Konsumen. Jakarta: Erlangga.

Pavlou, P.A., \& Fygenson, M. (2006, March). Understanding and Predicting Electronic Commerce Adoption: an Extension of the Theory of Planned Behavior. MIS Quarterly, 30(1), 115-143.

Raut, R.K., Kumar, R., \& Das, N. (2020, July 29). Individual Investors' Intention towards SRI in India: An Implementation of the Theory of Reasoned Action. Social Responsibility Journal, 6.

Rosen, B.N., Sandler, D.M., \& Shani, D. (1991). Social Issues and Socially Responsible Investment Behavior: A Preliminary Empirical Investigation. Journal of Consumer Affairs, 25(2).

Saputra, J., Astuti, D., \& Pertiwi, D. (2021). Effect of Financial Literacy, Risk Attitude and Saving Motives to Disposition Bias on Mutual Funds Investors. International Journal of Financial and Investment Studies, 2(1), 27-33. https://doi.org/10.9744/ijfis.2.1.27-33

Stella, G.P., Filotto, U., \& Cervellati, E.M. (2020). A Proposal for A New Financial Literacy Questionnaire. International Journal of Business and Management, 15(2), 34-48.

Subandi, J.R., \& Basana, S.R. (2021). The Effect of Salience and Disposition Effect on Stock Investment Decisions on Investors in Surabaya. International Journal of Financial and Investment Studies, 1(2), 77-84. https://doi.org/10.9744/ijfis.1.2.77-84 
Swanson, V., Power, K., Kaur, B., Carter, H., \& Shepherd, K. (2006). The Impact of Knowledge and Social Influences on Adolescents' Breastfeeding Beliefs and Intentions. Public Health Nutrition, 9(3), 297-305.

Taylor, S., \& Todd, P.A. (1995). Understanding Information Technology Usage: A Test of Competing Models. Information Systems Research, 6(2), 144-176.

Venkatesh, V., \& Davis, F.D. (2000, February). A Theoretical Extension of the Technology Acceptance Model: Four Longitudinal Field Studies. Management Science, 186-204.

Wahono, H.K., \& Pertiwi, D. (2020). Pengaruh Financial Literacy, Materialism, Compulsive Buying terhadap Propensity to Indebtedness. International Journal of Financial and Investment Studies, 1(1), 1-14. https://doi.org/10.9744/ijis.1.1.1-14.

Zeitham, V.A., Berry, L.L., \& Parasuraman, A. (1996). The Behavioral Consequences of Service Quality. Journal of Marketing, 60(2), 31-46. 